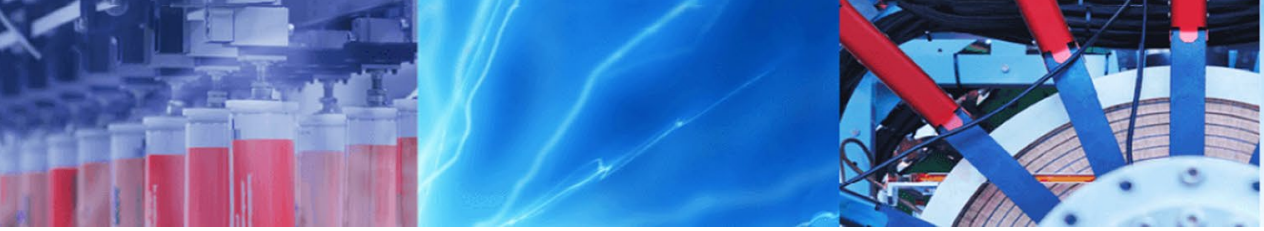

Research Article

\title{
Biosorption of hexavalent chromium metal ions from an aqueous solution of leaves and bark of Cinnamomum verum via green route
}

\author{
Benish Saeed ${ }^{1} \cdot$ Humera Anwer $^{1} \cdot$ Sumra Naqvi $^{1} \cdot$ Asma Siddiqui $^{1} \cdot$ Sobia Hashim $^{1}$
}

Received: 10 January 2020 / Accepted: 25 February 2020 / Published online: 2 March 2020

(c) Springer Nature Switzerland AG 2020

\begin{abstract}
In present research work Cinnamomum verum leaves $(\mathrm{CL})$ and barks $(\mathrm{CB})$ are exploited to encounter their effectiveness against the concentration of hexavalent chromium $\left(\mathrm{Cr}^{+6}\right.$ metal ions) through biosorption process. To achieve this goal optimal conditions were set and broken into various parts such as; doses of adsorbents, concentrations of adsorbates, variations in contact and stirring time $(5-100 \mathrm{~min})$, temperatures $\left(10^{\circ} \mathrm{C}\right.$ to $\left.50^{\circ} \mathrm{C}\right)$ and $\mathrm{pHs}$ from acidic to basic range $(1$ to 12). Thermodynamic parameters were also applied to validate the assay, which shows that the process is endothermic with positive $\Delta \mathrm{H}^{\circ}$ values, while negative values of $\Delta \mathrm{G}^{\circ}$ proved the spontaneous nature of sorption. Moreover, Lagergren's kinetic equations were employed, which suggest that the observed reaction process followed the dynamics of pseudosecond order. Equilibrium adsorption isotherms namely Langmuir and Freundlich have been applied to study the adsorbate materials attraction towards $\mathrm{Cr}^{+6}$ metal ions. The determined adsorption capability, i.e. $\mathrm{q}_{\mathrm{e}}$ was found to be 11.33 and $26.85 \mathrm{mg} / \mathrm{g}$ acquired by $\mathrm{CL}$ and $\mathrm{CB}$ at $30^{\circ} \mathrm{C}$ and $40^{\circ} \mathrm{C}$, respectively. FT-IR spectrums of loaded and unloaded metal ions were taken, which confirmed the participated functional groups of herbal plants in biosorption process. EDX analysis revealed the presence of $\mathrm{Cr}^{+6}$ metal ions after biosorption process. Furthermore, irregularities on surface of adsorbent material obtained from SEM images have provided more support to results for validation.
\end{abstract}

Keywords Cinnamomum verum leaves $\cdot$ Cinnamomum verum bark $\cdot \mathrm{Cr}^{+6}$ metal ions $\cdot$ Thermodynamics study . Adsorption dynamics · Adsorption isotherms

\section{Introduction}

Industrialization and mining actions, rapidly increases the heavy metals contamination in aquatic systems [25, 44]. It's a well-known fact that even at very low concentration heavy metals are highly toxic to humans $[14,15]$. They encounter human body in different ways, such as by inhalation, skin contact or using of those vegetables, which grew in sewage water or industrial effluents, etc. Consequently, they disturbed the metabolic processes and destroyed social health by accumulating in living creatures [17, 22]. Many synthetic mediators have been used to take out the heavy metals from the body, but they had shown an adversarial side effects as per medical evidence. However, herbs have no side effects and they can be used conveniently as an alternative to those synthetic mediators [56].

Chromium is counted as one of the most significant pollutant amongst top sixteen toxic metals, due to its carcinogenic appearances towards humans [20]. However, trivalent chromium present in water and food in trace volume seems benign. While hexavalent chromium is mutagenic, not essential for mammals and has no biological confirmation $[16,36]$.

\footnotetext{
$\triangle$ Humera Anwer, humera.fuuast@gmail.com; Benish Saeed, beenishahmed781@gmail.com; Sumra Naqvi, sumra.naqvi@gmail.com; Asma Siddiqui, asmasiddiqui1091@gmail.com; Sobia Hashim, sobiahashim6@gmail.com | Department of Chemistry, Federal Urdu University Art, Science and Technology, Gulshan-e-lqbal Campus, Karachi 75300, Pakistan.
} 
Therefore, an extensive time duration disclosure of $\mathrm{Cr}^{+6}$ metal ions above the proposed level caused severe damage to chief bio-systems [38], organs and skin of the body like, circulatory system, liver and kidney impairment, nerve dermatitis [28], nasal septum perforation [39], skin ulceration [10], skin cancer [34] and lung cancer etc. [24]. Several types of allergic responses have also been familiar like swelling and redness to the skin [9].

Subsequently, over the wide range of $\mathrm{pHCr}^{+6}$ oxyanions are soluble in water and can easily accumulate into underground water and pollute the consumption water [21,23, $27,31,37,43,45-47,57]$. Permitting to the world health association in 2008 the authorized boundary of $\mathrm{Cr}^{+6}$ metal ions in consumption water that is $0.05 \mathrm{mg} / \mathrm{L}$ [52]. The EPA (Environmental Protection Agency) of USA fixed a concentrated pollutant limit up to $38 \mu \mathrm{g} / \mathrm{L}$ for entire chromium in taking water $[54,55]$.

Bioinorganic with the unison of green chemistry (which is new efficacious and unfurl branch of chemistry), encourages the designs of product and process that omit or lessen the usage and propagation of hazardous constituents which are harmful for human, animals, plants and the environment.

Among several biodegradable adsorbents plants have productive, constructive, powerful and virtual qualities. They do not only make our environment fresh and striking but also they have been using in culinary, medicinal and some spiritual purposes since long ago [41]. They are combusted patently after adsorption and desorption mechanisms and their microstructure can be investigated comprehensively [32].

Ayurveda was the most ancient cure of a system which is still widely used in Asian countries [12]. Modern medicinal techniques in amalgamation of Ayurveda bring high quality, quick action herbal products with good bioavailability. Different combinations of herbs, amino acids and other nutritional supplements found to be healthier substitutes of chelating agents. They may take longer time to clear the toxic metals and unsafe chemicals from the body, but safer to use with no or minor side effects. In contrast, chelation therapy is the treatment to remove the heavy metals and toxic chemicals in clinical toxicology, but can prove incurable [19].

In the current reserch, $\mathrm{CL}$ and $\mathrm{CB}$ are used as natural adsorbents under optimize conditions at vitro level. $\mathrm{CL}$ is often known as Bay leaf. It is also used for culinary and medicinal purposes. CB is a common spice used in both sweet and savory items of food. It is employed in cookery as condiment and flavoring the material. In Mexico, it is used in the preparation of chocolate specially [49].

Hence, existing paper concentrated to investigate the adsorption of $\mathrm{Cr}^{+6}$ metal ions by the leaves and bark of Cinnamomum verum at the optimize parameters. The mechanism of biosorption was studied by the number of isotherms and thermodynamics. Kinetics was also established to determine the efficacy of assay. Moreover, sophisticated instrumental techniques were used to support the obtained results.

\section{Experimental process}

\subsection{Chemicals}

Analytical grade chemicals were utilized during the investigation work. Double deionized water (D.I water) was used for the preparation of samples and stock solutions. Potassium dichromate $\left(\mathrm{K}_{2} \mathrm{Cr}_{2} \mathrm{O}_{7} \approx 99.0 \%\right)$ by ACS reagent, Diphenyl Carbazide (DPC $\approx 98.0 \%$ ) from ph. Eur. Reagent, $\mathrm{HCl}\left(37 \%\right.$ with $1.2 \mathrm{~g} / \mathrm{mL}$ density at $\left.25^{\circ} \mathrm{C}\right), \mathrm{NaOH}$ pellets analytical ACS reagent (with $\approx 98 \%$ ), Sodium chloride $(\mathrm{NaCl} \approx 99.0 \%) \mathrm{H}_{2} \mathrm{SO}_{4}(99.999 \%)$ and Acetone (with $\approx 99.9 \%$ ) were obtained from Sigma Aldrich. All the chemicals were used as per received.

\subsection{Instrumentation}

Pulverized and weighed the adsorbent samples through an electric grinder (Kenwood) and weighing balance (ER120A). $\mathrm{pH}$ of stock and sample solutions were mentained by the $\mathrm{pH}$ meter (HANNA pH 211). An electrical ThermoShaker (Model: MS-100) was cast off to agitate the sample solutions. SPR (surface plasmon resonance) analysis was inspected by Visible spectrophotometer (Jenway 6310; $320-900 \mathrm{~nm}$ ) to quantify the $\mathrm{Cr}^{+6}$ metal ions adsorption, For FTIR spectrum, Fourier transform Infrared Spectroscope (model NICOLET 67000) was used. Scanning Electron microscope (model JSM 6380A) by ASEM of JEOL Japan used to study the surface of adsorbents. Chemical composition of biosorbents analyzed by EDS Spectroscopy (model JMV 54175) between 0 and $10 \mathrm{kV}$.

\subsection{Preparation of stock solution}

All glassware was cleaned initially by soaking in acidified water $(0.1 \mathrm{M} \mathrm{HCl})$ and washed carefully using tap water which followed by D.I water and acetone. A stock solution of $\mathrm{Cr}^{+6}$ metal ions of $0.1 \mathrm{M}$ was made via taking an appropriate quantity of $\mathrm{K}_{2} \mathrm{Cr}_{2} \mathrm{O}_{7}$ in a $100 \mathrm{~mL}$ volumetric flask (acidified it with one drop of $\mathrm{HCl}(0.1 \mathrm{M})$ ) and filled up to the mark with D.I water. Serial dilutions were also made as per desire employed concentrations. $\mathrm{H}_{2} \mathrm{SO}_{4}(0.1 \mathrm{M})$ stock solution was made in $50 \mathrm{~mL}$ which was further used for making up the complex solutions of $\mathrm{Cr}^{+6}$ with Diphenyl carbazide (DPC) in the series. For this purpose, 25\% DPC was taken into service by making in $100 \mathrm{~mL}$ of volumetric 
flask for complexation. Priory $0.257 \mathrm{~g}$ of DPC was dissolved in $50 \mathrm{~mL}$ of acetone and later made up it with D.I water up to the mark.

\subsection{Preparation of biosorbents}

Commercially available $\mathrm{CL}$ and $\mathrm{CB}$ were bought from the Metro super store of Karachi, Pakistan and were used directly without any reform. Both adsorbents were washed initially with plenty of tap water then rinsed with D.I water to remove the deposits of dust. The $\mathrm{CB}$ and $\mathrm{CL}$ were then desiccated in oven for overnight at $105^{\circ} \mathrm{C}$. Dehydrated adsorbents were grinded in grinder to acquire a larger surface area and then sieved ( 20 to $200 \mu \mathrm{M}$ ) to attained the same particle size of adsorbents throughout the testing because variable particle sizes may influence the result [48]. Different particle sizes of adsorbents by $(20,50,100$ and $200 \mu \mathrm{M}$ size) were separated through the concerned sieve to select the favorable particles size for maximum adsorption.

\subsection{Biosorption procedure}

At ambient temperature, the percent biosorption was examined onto both of adsorbents by using the batch technique. The fixed amount of adsorbents $C L$ and $C B$ were added separately into $25 \mathrm{~mL}$ of $\mathrm{Cr}^{+6}$ metal ions solution of $0.1 \mathrm{M}$ concentration in an Erlenmeyer flask. These mixtures were shaken thoroughly in electrical shaker for particular time (30 min) with a rotating speed of $120 \mathrm{rpm}$. After that mixture was filtered using wattman filter paper (1442-25 ashless grade 42 with $12.5 \mathrm{~cm}$ and $2.5 \mu \mathrm{m}$ pore size) through suction pump. Finally, the un-adsorbed concentrations of $\mathrm{Cr}^{+6}$ metal ions were measured by making complex with a fixed amount of DPC. Solutions were made up with $\mathrm{H}_{2} \mathrm{SO}_{4}(0.1 \mathrm{M})$ up to the mark [3]. The results were analyzed by Visible spectrophotometer at $540 \mathrm{~nm}$. All the experiments were repeated in triplicate manner and mean values were used for calculations and displays.

\subsection{Analysis of $\mathrm{Cr}^{+6}$ metal ions solution}

The un-adsorbed concentration of $\mathrm{Cr}^{+6}$ metal ions in the supernatant liquid sample (after filteration) was analyzed by the Visible spectrophotometer through DPC assay. The difference in concentrations from original to obtained is measured by the support of the following equation;

$q_{t}=v\left(C_{o}-C_{e}\right) / M$

whereas $\mathrm{q}_{\mathrm{t}}(\mathrm{mg} / \mathrm{g})$ is the $\mathrm{Cr}^{+6}$ metal ions up taking power of adsorbents after a certain time, $V(L)$ is the volume of $\mathrm{Cr}^{+6}$ metal ions in solution in contact with the biosorbents,
$\mathrm{C}_{0}$ and $\mathrm{C}_{\mathrm{e}}(\mathrm{g} / \mathrm{L})$ are the initial and remaining concentration of $\mathrm{Cr}^{+6}$ metal ions respectively and $\mathrm{M}(\mathrm{g})$ is the extent of adsorbents used throughout the experimentation.

However, the deletion percentage of $\mathrm{Cr}^{+6}$ metal ions from the solution were measured as;

$\% R=C_{o}-C_{e} / C_{o} \times 100$

while $\mathrm{R}$ is the deduction percentage of $\mathrm{Cr}^{+6}$ metal ions from the mixture solution, $C_{o}$ and $C_{e}(g / L)$ are the concentrations at initial level and after achieving equilibrium respectively.

\subsection{Zero-point charge determination}

For determination of zero-point charge (ZPC), $\mathrm{NaCl}$ of $0.01 \mathrm{M}$ as an electrolyte added in $\mathrm{HCl} / \mathrm{NaOH}(0.1 \mathrm{M})$ solutions. Tests were performed by introducing $25 \mathrm{~mL}$ of electrolyte into the 10 beakers and later the initial pH was maintained to the required values in the range of 2-12. Optimized amounts of $C L$ and $C B$ were added into each beaker separately and kept for $48 \mathrm{~h}$ under agitation. After $48 \mathrm{~h}$, the adsorbents were filtered and measured the final $\mathrm{pH}$ of each beaker. The graph was plotted between final against initial pH to get the ZPC of each adsorbent [51].

\section{Results and discussion}

\subsection{Biosorption studies}

\subsubsection{Particle size}

To analyze the influence of particle size of biomasses for adsorption of $\mathrm{Cr}^{+6}$ metal ions, different mesh sizes were checked for getting maximum adsorption. Experiments were done on $20,50,100$ and $200 \mu \mathrm{m}$ sizes of both biosorbents i.e. $\mathrm{CL}$ and $\mathrm{CB}$. Results presented that uptake of $\mathrm{Cr}^{+6}$ metal ions were gradually increased from larger to smaller size of adsorbents particles. It means as particle size reduces the system got a greater surface area for biosorption with reduction in the external mass transfer resistance. Experimental outcomes shown the best result were collected at the $20 \mu \mathrm{m}$ size of both adsorbents particles Fig. 1a.

\subsubsection{Adsorbents dose}

The adsorbent quantity is an essential element, which encourages metal ions up take from the original concentration caused by the availability of unoccupied tie positions. In present research effect of adsorbent doses were supported to find out the optimum adsorption of $\mathrm{Cr}^{+6}$ 

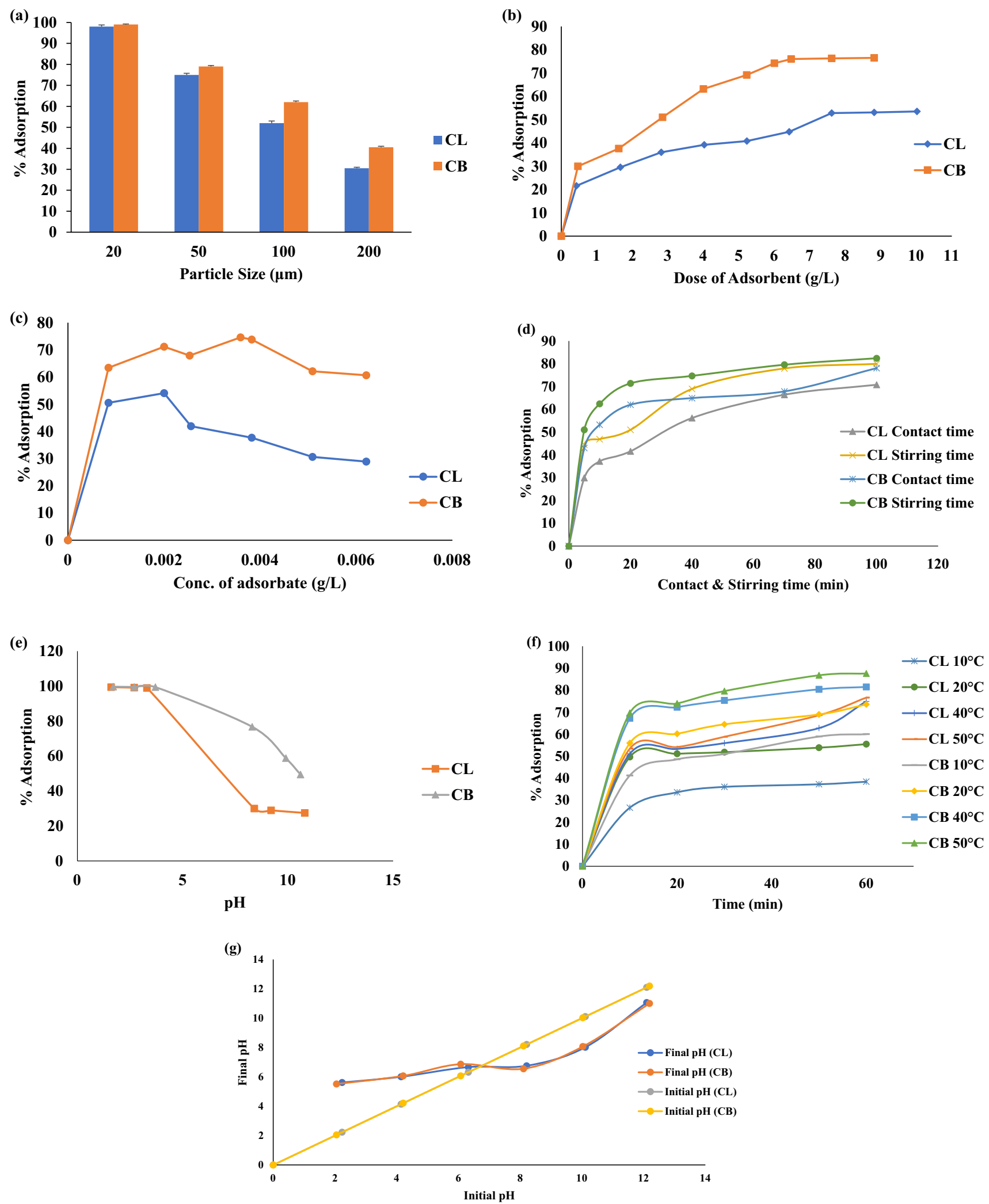

Fig. 1 Optimized parameters a Particle size variation $\mathbf{b}$ Effect of Adsorbents $\mathbf{c}$ Effect of Adsorbate $\mathbf{d}$ Effect of Contact \& Stirring Time e Effect of $\mathrm{pH} \mathbf{f}$ Effect of Various Temperature with respect to time $\mathbf{g}$ Zero-point charge $\mathrm{CL}$ and CB 
metal ions with a changeable quantity of $\mathrm{CL}$ and $\mathrm{CB}$ from $0.424 \mathrm{~g} / \mathrm{L} \& 0.468 \mathrm{~g} / \mathrm{L}$ to $10.020 \mathrm{~g} / \mathrm{L} \& 8.812 \mathrm{~g} / \mathrm{L}$ respectively at optimized conditions. The amount of $\mathrm{Cr}^{+6}$ metal ions bio-sorption increases from 21.6 to $53.5 \%$ and 30 to $76.5 \%$ for $C L$ and $C B$ as shown in Fig. $1 \mathrm{~b}$ respectively. The results revealed that the percent adsorption of $\mathrm{Cr}^{+6}$ metal ions risen as per the amount of adsorbent increases till a maximum plateau of adsorption was attained. It may have caused by the restricted accessibility of adsorbing specie for a greater surface sites of adsorbent [8]. However, in contrary conditions high adsorbent dosage begun screening effect and shielded the binding sites of adsorbent $[13,40]$. The greatest adsorption was noted at $7.6 \mathrm{~g} / \mathrm{L}$ and $6.4 \mathrm{~g} / \mathrm{L}$ of $C L$ and $C B$ respectively.

\subsubsection{Adsorbate concentration}

The biosorption of $\mathrm{Cr}^{+6}$ metal ions on $\mathrm{CL}$ and $\mathrm{CB}$ were between the concentrations of $8.4429 \mathrm{e}-4$ to $6.207 \mathrm{e}-3(\mathrm{~g} / \mathrm{L})$. While the applied concentrations of herbs were $5.2 \mathrm{~g} / \mathrm{L}$ and $6.0 \mathrm{~g} / \mathrm{L}$ for $\mathrm{CL}$ and $\mathrm{CB}$ respectively. The adsorption ability decreases from 50.52 to $28.91 \%$ and 63.41 to $60.66 \%$ for $\mathrm{CL}$ and $\mathrm{CB}$ Fig. 1c. These results exposed the progressive decline in the electrostatic communication in the middle of adsorbate and active locations of adsorbents. $\mathrm{As} \mathrm{Cr}^{+6}$ metal ion concentration increases the power of adsorption decreases due to less adsorption situates. Hence, smaller numbers of available surface sites decline the adsorption volume [30].

\subsubsection{Contact time}

Deduction of $\mathrm{Cr}^{+6}$ metal ions adsorption was improved by the rise of interaction time of adsorbate and adsorbent from 5 to $100 \mathrm{~min}$. Each mixture of metal ion solution with $\mathrm{CL}$ and $\mathrm{CB}$ acquires equilibrium at 90 and 66 min with 69.01 and $76.52 \%$ of adsorption efficiency respectively. The deduction of $\mathrm{Cr}^{+6}$ metal ions from aqueous solution was found to be time dependent behavior, when all further parameters were kept constant. As an economical fact of view, these effects shown excessive significance for wastewater treatment..

\subsubsection{Stirring time}

The outcomes described the variation in adsorption arisen at different time intervals from 5 to $100 \mathrm{~min}$ at constant similarity as above. Optimum adsorption of $\mathrm{Cr}^{+6}$ metal ions was at 60 and 55 min with 66.96 and $77.5 \%$ for $C L$ and CB. Rapid and progressive change appeared in adsorption process which reveals that equilibrium has achieved fast with stirring during the equal time intervals Fig. $1 \mathrm{~d}$.
The above results also shown that the nonstop stirring facilitate the active sites for adsorption of $\mathrm{Cr}^{+6}$ metal ions process. The results displayed that the steadiness between adsorbate and adsorbent has attained rapid during stirring time as related to simple interaction time.

The abstraction of $\mathrm{Cr}^{+6}$ metal ions by biosorption procedure during mechanical stirring may follows the metal ions travel from the bulk of the solution to adsorbent surface mechanism more swiftly. This may lead to metal ion transmission was occurred from next to the periphery surface layer of the adsorbent and Intra-particle diffusion of metal ions occurred into the internal stomas of adsorbent [7].

\subsection{6 pH}

Most favorable adsorption of $\mathrm{Cr}^{+6}$ metal ions examined by regulating $\mathrm{pH}$. Difference in $\mathrm{pH}$ is directly influencing the competitive power of $\mathrm{H}^{+}$ions with metal ions for the active empty sites of the absorptive surface [50]. The significance of $\mathrm{pH}$ on the adsorption of $\mathrm{Cr}^{+6}$ metal ions for both $\mathrm{CL}$ and $C B$ were studied between the range of 1 to 11 . Results are indicated, that maximum adsorption was achieved at acidic $\mathrm{pH} 1.6$ and 2.7 at 99.42 and $99.51 \%$ adsorption of $\mathrm{CL}$ and $\mathrm{CB}$ Fig. 1 e.

As per reported in literature that the acidic medium following species of chromium were coexisted i.e. $\mathrm{HCrO}^{-4}$, $\mathrm{CrO}_{4}^{-2}, \mathrm{Cr}_{3} \mathrm{O}_{10}^{-2}, \mathrm{Cr}_{4} \mathrm{O}_{13}^{-2}$ and $\mathrm{Cr}_{2} \mathrm{O}_{7}^{-2}$ but only $\mathrm{Cr}_{2} \mathrm{O}_{4}^{-2}$ is stable and existed at above $8 \mathrm{pH}$ so if the $\mathrm{pH}$ decreases the equilibrium shifts to dichromate [42].

$2 \mathrm{CrO}_{4}^{-2}+2 \mathrm{H}^{+} \leftrightarrow \mathrm{Cr}_{2} \mathrm{O}_{7}^{-2}+\mathrm{H}_{2} \mathrm{O}$

Thus at extremely low $\mathrm{pH}$ these species are at risk to adsorb on the dynamic protonated positions of adsorbent $[18,53]$.

According to the literature survey of plants, they contain a great range of functional groups like phenol and alcohol [11]. However, in acidic medium the phenolic group of bio-sorbent become protonated due to electrostatic force of attraction and may interact with the $\mathrm{HCrO}^{-4}$ ions. Therefore, according to results, it shows that the chemisorption process may have occurred at higher acidic $\mathrm{pHs}$. While at higher $\mathrm{pHs}$ the bio-sorbent's surface may have becomes more negative, which creates repulsion between surface and $\mathrm{HCrO}^{-4}$ ions and down the rate of adsorption [29].

\subsubsection{Temperature variation with time}

The influence of temperature by varying time is another non neglected factor because it provides information related to the surface interaction nature of adsorbent and adsorbate. For this purpose, experiments of percent 
adsorption of $\mathrm{Cr}^{+6}$ metal ions done by altering temperature from 10 to $50^{\circ} \mathrm{C}$ at comparable time breaks from 10 to $60 \mathrm{~min}$. Consequently, the percent adsorption of metal ions increased from 26.57 to $76.64 \%$ and 41.22 to $87.59 \%$ for $C L$ and $C B$ respectively as temperature and varying time periods increased from lower to higher range. Early attainment of equilibrium exposes the adsorption route of $\mathrm{Cr}^{+6}$ metal ions is endothermic in manner [1].

By the rise of temperature, process of adsorption increases, which can be due to increase of strong interaction forces between absorbent and metal ions. These obtained results also supported the chemisorption process, as similar behavior was also supported by earlier workers Fig. 1f.

\subsubsection{Zero-point charge (ZPC)}

Initial $\mathrm{pH}$ of $\mathrm{CL}$ and $\mathrm{CB}$ moves from 12.10 and 12.19 to 11.07 and 11.01 correspondingly, implying that both of adsorbents have a positive surface charge. It means they were acidic in a form which directly attract or adsorb the negative ions from the solution and reduces its $\mathrm{pH}$ from high to low.

The point of transition of the adsorbent material where the surface charge becomes negative from positive i.e. The point where it turns from acidic to basic and at this point the charge of the surface will be zero. According to experimental results 6.32 and 6.54 are points of transition for $C L$ and CB Fig. 1g.

\subsubsection{Characterization}

The FTIR measurement were carried out to assess the participated biomolecules of $C L$ and $C B$ which are responsible for $\mathrm{Cr}^{+6}$ metal ions bio-sorption. The key frequencies of vibrations and their comparable groups that associated to $\mathrm{Cr}^{+6}$ metal ions are directed in Table 1 .
It seems that there were some deviations in absorption peak frequencies between free and $\mathrm{Cr}^{+6}$ loaded infrared spectrum. The noticeable shift scene at the site of $-\mathrm{OH}$ and $-\mathrm{NH}_{2}$ stretching vibrational group ranging from 3290 and 3336 to 3330 and $3335 \mathrm{~cm}^{-1}$ in CL and CB. While CL showed a slight change in peak from 1436 to $1418 \mathrm{~cm}^{-1}$ because of a minor association with $\mathrm{C}-\mathrm{OH}$ bending group. $\mathrm{CB}$ exposed another change from 1248 to $1242 \mathrm{~cm}^{-1}$. This can also attribute to the stretching vibration of the $\mathrm{C}-\mathrm{OH}$ group. These transferals proposed that there was a typical procedure happened amongst ionizable functional groups and $\mathrm{Cr}^{+6}$ metal ions. Therefore, the strong shift in peak locations of $-\mathrm{OH}$ and $-\mathrm{NH}_{2}$ stretching, vibration indicated that $\mathrm{Cr}^{+6}$ metal ions was interected by carboxyl, hydroxyl and amide functional groups present on the outside surface of both adsorbents. Nevertheless, remaining differences in peaks shifting among all three adsorbents revealed the diverse levels of degree of association Fig. 2.

Moreover, the SEM images of CL and CB before adsorption show the bearing of many empty seats and tiny holes on the surface. Since high surface area and porous structures were the basic parameters for an effective adsorbent. However, after treatment with $\mathrm{Cr}^{+6}$ metal ions the vacant places of adsorbent were filled [2, 6, 33] (Fig. 3a-d).

The localized elemental information of both adsorbents $\mathrm{CL}$ and $\mathrm{CB}$ determined by EDX analysis (Fig. 3e-h). The obtained spectrum results showed the presence of $\mathrm{Cr}^{+6}$ metal ions in treated sample which indicates the successful adsorption of $\mathrm{Cr}^{+6}$ metal ions. However, presence of the other small metal ions impurities may have arisen due to the number of other plant constituents [3].

\subsubsection{Adsorption isotherms}

Isotherms are prerequisite requirement which are needed to understand the adsorption mechanism [26]. The observational data with various temperatures of each adsorbent were analyzed to understand the adsorption manner of

Table 1 Main frequencies of vibrations and their corresponding groups

\begin{tabular}{|c|c|c|c|c|c|}
\hline \multirow[t]{2}{*}{ S.No } & \multicolumn{2}{|c|}{ Cinnamomum leaves } & \multicolumn{2}{|c|}{ Cinnamomum bark } & \multirow[t]{2}{*}{ Bonds indicative } \\
\hline & $\begin{array}{l}\text { Controlled } \\
\left(\mathrm{cm}^{-1}\right)\end{array}$ & $\begin{array}{l}\mathrm{Cr}^{+6} \\
\text { loaded }\left(\mathrm{cm}^{-1}\right)\end{array}$ & $\begin{array}{l}\text { Controlled } \\
\left(\mathrm{cm}^{-1}\right)\end{array}$ & $\begin{array}{l}\mathrm{Cr}^{+6} \\
\text { loaded }\left(\mathrm{cm}^{-1}\right)\end{array}$ & \\
\hline 1 & 3290 & 3330 & 3336 & 3335 & $\mathrm{R}-\mathrm{OH}$ group or $-\mathrm{NH}_{2}$ group \\
\hline 2 & 2920 & 2921 & 2917 & 2917 & $\mathrm{CH}$ - symmetric and asymmetric stretching \\
\hline 3 & 2360 & 2360 & 2360 & 2360 & stretching vibrations of $-\mathrm{NH}_{2}{ }^{+},-\mathrm{NH}^{+}$and $-\mathrm{NH}$ groups of biomass \\
\hline 4 & 1615 & 1615 & 1635 & 1636 & $\mathrm{C}-\mathrm{COO}-$ and $\mathrm{C}=\mathrm{C}$ stretching associated to the aromatic bond \\
\hline 5 & 1436 & 1418 & 1456 & 1457 & $\mathrm{C}-\mathrm{OH}$ bending and stretching vibration of phenols respectively \\
\hline 6 & 1015 & 1015 & 1034 & 1038 & CO vibration of alcoholic group \\
\hline 7 & - & - & 1733 & 1732 & stretching vibration of $-\mathrm{CO}$ of carboxylic group \\
\hline 8 & - & - & 1158 & 1157 & $\mathrm{CN}$ stretching vibration of amine \\
\hline
\end{tabular}



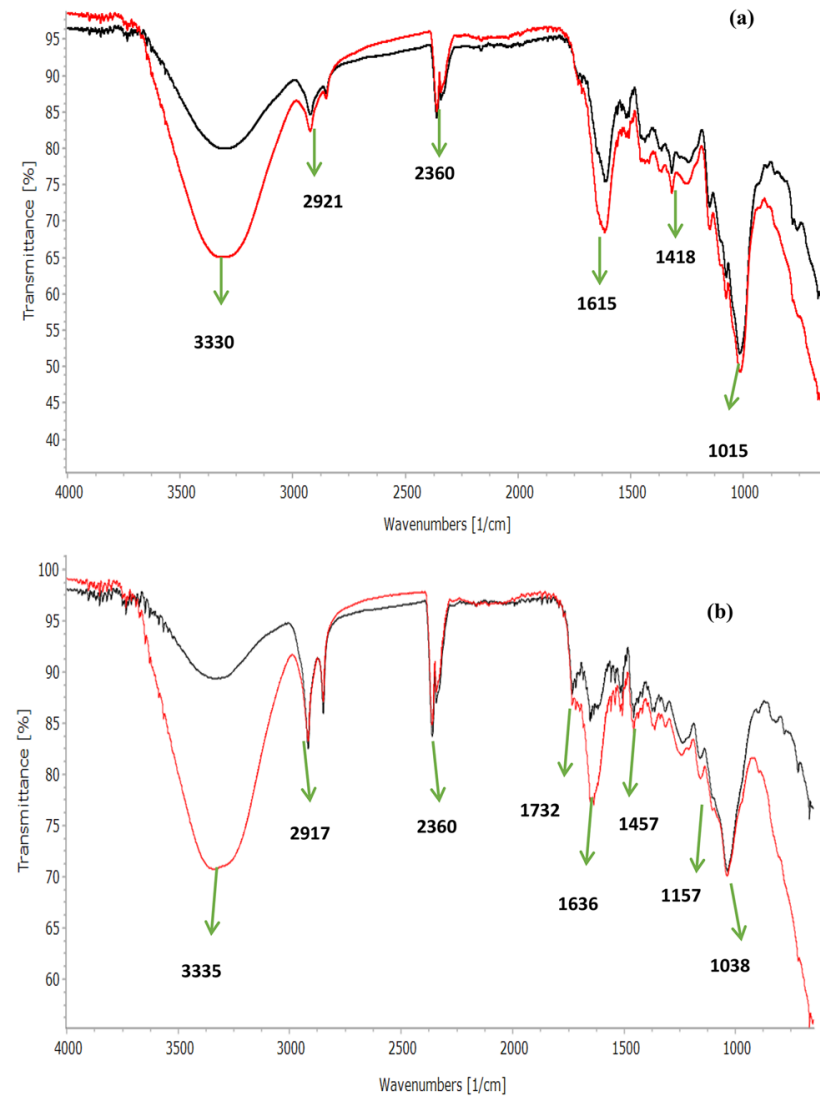

Fig. 2 FTIR Spectrum a Unloaded and loaded $\mathrm{Cr}^{+6} \mathrm{CL}$ b Unloaded and loaded $\mathrm{Cr}^{+6} \mathrm{CB}$

the finest fitted theoretical model. The data was collected at room temperature, $10^{\circ}, 20^{\circ}, 40^{\circ}$ and $50^{\circ} \mathrm{C}$. All temperatures were used to calculate Langmuir Fig. 4 and Freundlich Fig. 5 isotherms to get comparative analysis.

Following is the linearized Langmuir isotherm equation was utilized.

$\frac{C_{e}}{x / m}=\frac{1}{q_{m}} C_{e}+\frac{1}{q_{m} \cdot K_{\mathrm{L}}}$

Here, $\frac{x}{m}$ is the extent of $\mathrm{Cr}^{+6}$ metal ions adsorbed for every unit mass of the adsorbent. $C_{e}$ is the equilibrium concentration of $\mathrm{Cr}^{+6}$ metal ions. While, $\mathrm{q}_{\mathrm{m}}$ is the single layer capacity that deals with the saturated amount of $\mathrm{Cr}^{+6}$ metal ion in solid phase. However, $\mathrm{K}_{\mathrm{L}}$ is the constant for Langmuir binding. The measures of $\mathrm{q}_{\mathrm{m}}$ and $\mathrm{K}_{\mathrm{L}}$ were assigned by the slopes and intercepts of linear plots between $\frac{C_{e}}{x_{/ m}}$ and $C_{e}$. Moreover, values of $K_{L}$ indicated the greater adsorption aptitude of bio-sorbents towards metal ions [4].

For calculation of the Freundlich isotherm following linearize equation was used. $\log \frac{X}{m}=\log \mathrm{K}_{\mathrm{F}}+\frac{1}{n} \log \mathrm{C}_{\mathrm{e}}$

where $\frac{X}{m}$ or qe is the quantity of adsorption over each gram of adsorbent and $C_{e}$ is the concentration at equilibrium of metal ions. $K_{F}$ and $\frac{1}{n}$ are the empirical constant associated to sorption capability and strength of Freundlich isotherm individually. They rely on the parameters of adsorbate, adsorbent, pressure and temperature. The isothermal diagram between $\log \frac{X}{m}$ and $\log C_{\mathrm{e}}$ shows a straight line with positive intercepts and slopes. Values of constant parameters of both aforementioned adsorption isotherms were listed in Table 2.

\subsubsection{Thermodynamic parameters}

Thermodynamic factors, the enthalpy $\left(\Delta \mathrm{H}^{\circ}\right)$, entropy $\left(\Delta \mathrm{S}^{\circ}\right)$ and Gibbs free energy $\left(\Delta \mathrm{G}^{\circ}\right)$ in adsorption are useful tools to define the nature of the adsorption mechanism whether it is endothermic or exothermic. These limits were calculated with the following equation,

$\ln \mathrm{K}_{\mathrm{c}}=\frac{-\Delta H^{\circ}}{R T}+\frac{\Delta S^{\circ}}{R}$

$\Delta \mathrm{G}^{\mathrm{o}}=-\mathrm{RT} \ln \mathrm{K}_{\mathrm{c}}$

$\mathrm{K}_{\mathrm{c}}=\frac{\mathrm{C}}{\mathrm{C}_{e}}$

where, $\mathrm{K}_{\mathrm{c}}$ is the constant of equilibrium, $\mathrm{C}(\mathrm{mg} / \mathrm{L})$ is the adsorbent concentration while $C_{e}(\mathrm{mg} / \mathrm{L})$ is the concentration of adsorbate at equilibrium condition. $R$ is the gas constant and $T$ is the temperature in Kelvin. $\Delta H^{\circ}$ and $\Delta S^{\circ}$ values were calculated by the help of slopes and intercepts as in Table 3. There were gradual increases in the $K_{c}$ values as temperature intensify which revealed the endothermic character of adsorption for both biosorbents Fig. 6 . The negative figures of free energy $\left(\Delta G^{\circ}\right)$ indicated that it was a spontaneous process and no energy barrier in sorption process was involved. The values of $\Delta G^{\circ}$ came to be more negative as temperature increases, which pointed towards greater driving force. These results exhibited the highest adsorption volume as temperature growths. The activation of adsorbent surface or enlargement of pore size attributed greater adsorption capacity at greater temperature [35].

Similarly, the plus values of $\Delta \mathrm{H}^{\circ}$ indicated the biosorption manner was endothermic. It occurs spontaneously only when entropy of the system increases and the values of $\Delta H^{\circ}$ are lesser than $T \Delta S^{\circ}$ values. $\Delta S^{\circ}$ values are positive which confirmed the increase in randomness with the addition of temperature at the solid surface and $\mathrm{Cr}^{+6}$ 

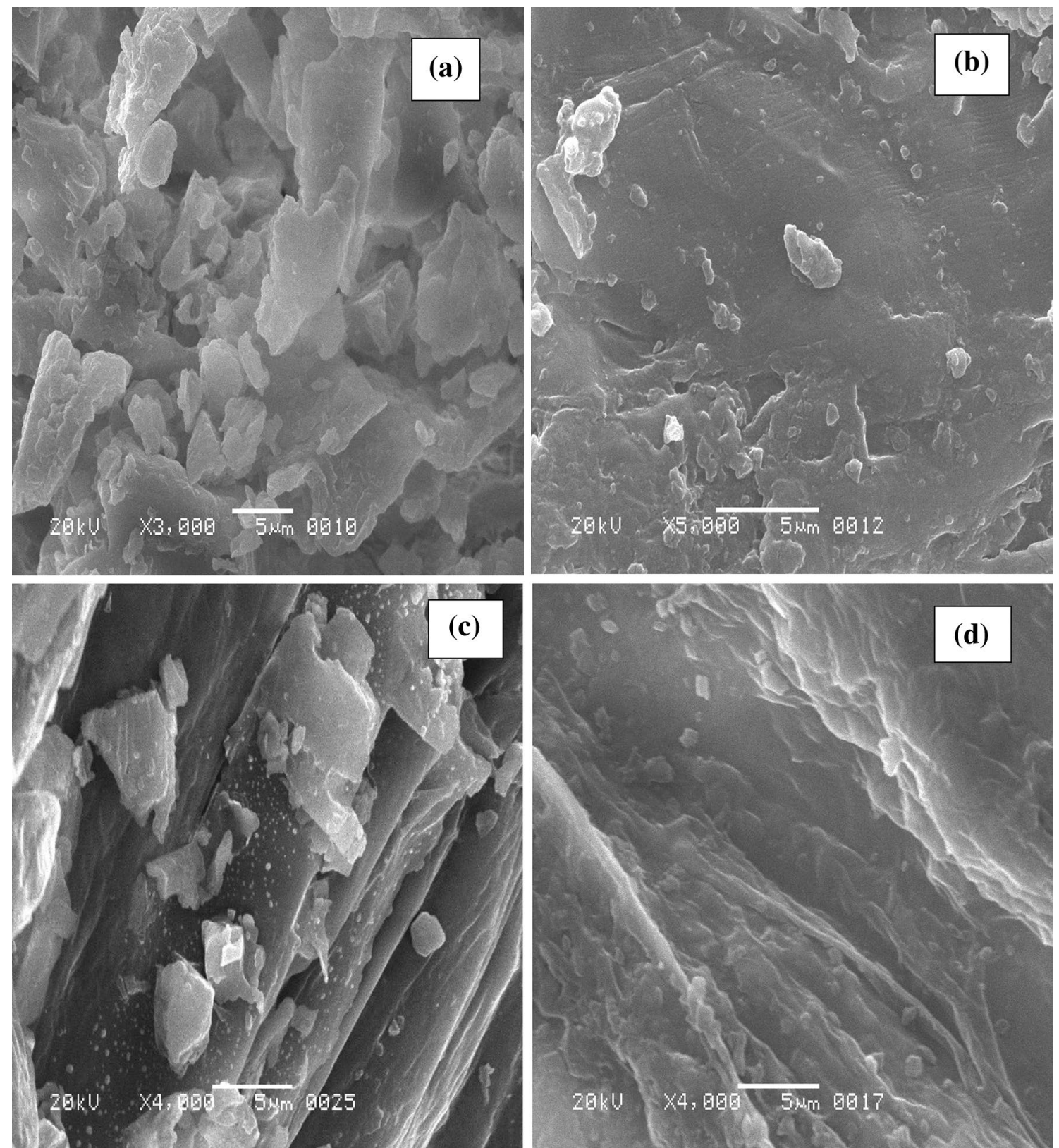

Fig. 3 SEM results of $\mathbf{a}$, $\mathbf{b}$ controlled and sample of $\mathrm{CL}$ and $\mathbf{c}$, $\mathbf{d}$ controlled and sample of $\mathrm{CB}$ respectively. EDX results of $\mathbf{e}$, $\mathbf{f}$ controlled and sample of $\mathrm{CL}$ and $\mathbf{g}$, $\mathbf{h}$ controlled and sample of $\mathrm{CB}$ correspondingly

metal ions solution border throughout adsorption phenomenon [5].

For the adsorption of $\mathrm{Cr}^{+6}$ metal ions on adsorbents, the change in activation energies were estimated via following Arrhenius equation:

$\log \mathrm{K}_{\mathrm{d}}=\log \mathrm{A}-\left(\mathrm{E}_{\mathrm{A}} / 2.303 \mathrm{RT}\right)$

where $K_{d}$ is the sorption rate constant $(\mathrm{g} / \mathrm{mol} \mathrm{s}), E_{A}$ is the energy of activation $(\mathrm{J} / \mathrm{mol}), A$ is the Arrhenius factor $(\mathrm{g} / \mathrm{mol} \mathrm{s}), R$ is the gas constant $(\mathrm{J} / \mathrm{K} \mathrm{mol})$ and $\mathrm{T}$ is the temperature. Activation energy values shown the chemical forces are regarded in the sorption process and probability of the mechanism Fig. 7. The values of its constant elements are prescribed in Table 4.

\subsubsection{Kinetic modeling}

Kinetic mechanism of adsorption was investigated by Lagergren's, kinetic representations for pseudo-first and pseudo-second order Fig. 8a, b. The experimental data 


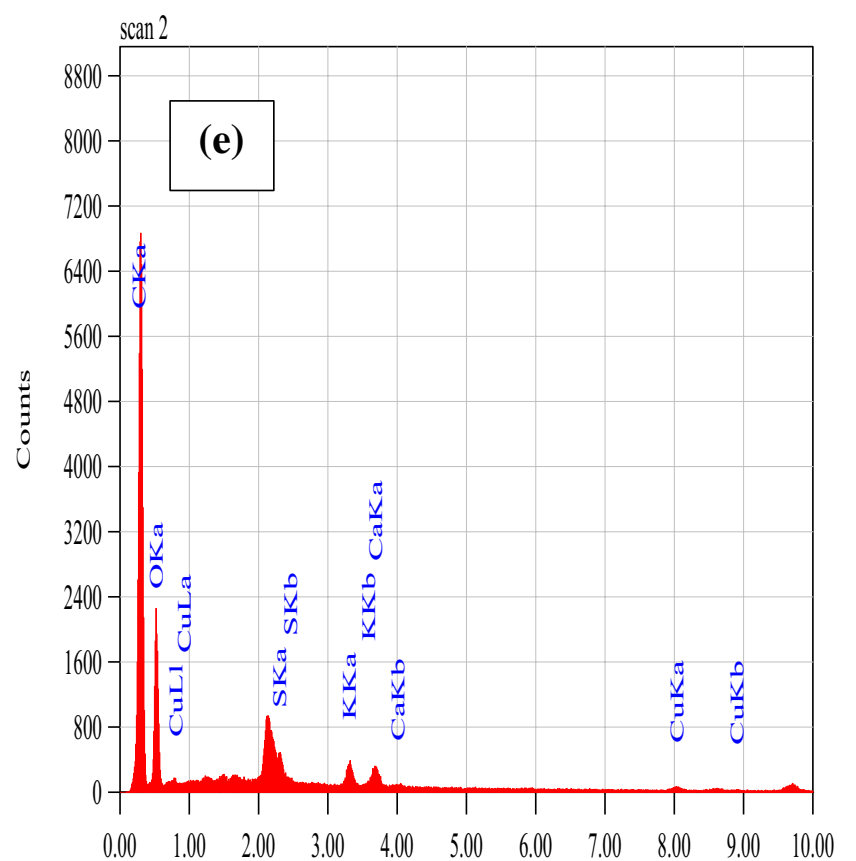

$\mathrm{keV}$

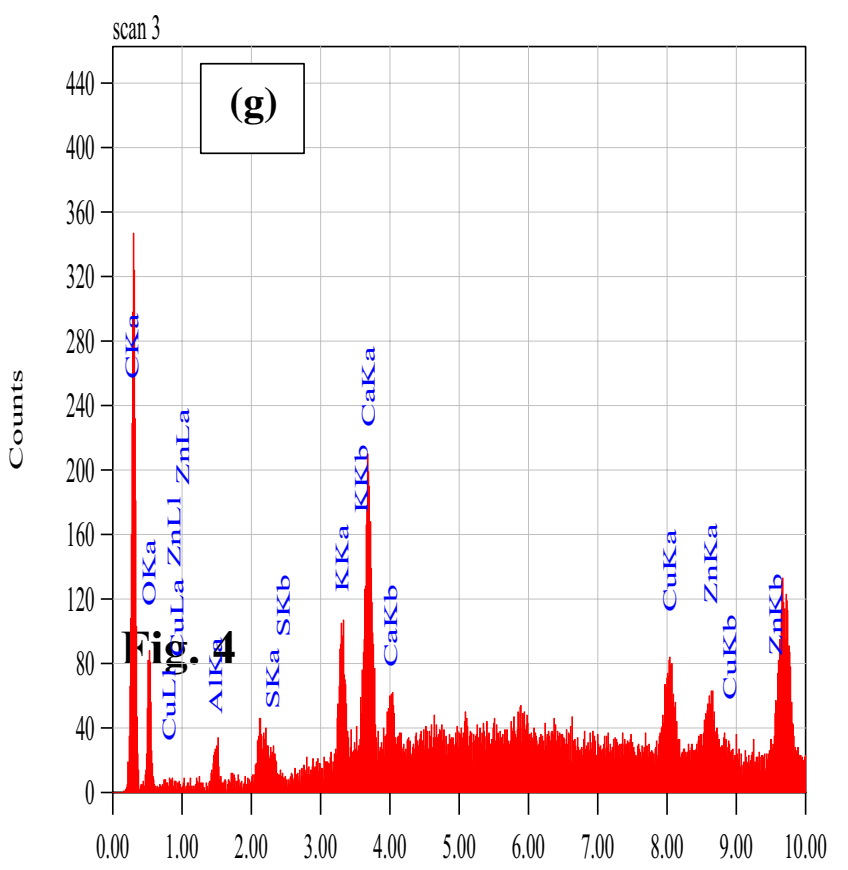

$\mathrm{keV}$

Fig. 3 (continued)

for both adsorbents were used to predict the adsorption kinetics. It was tested by the following equations;

For pseudo first order reaction, the equation is

$\log \left(q_{e}-q_{t}\right)=\log q_{e}-K_{1} / 2.303$

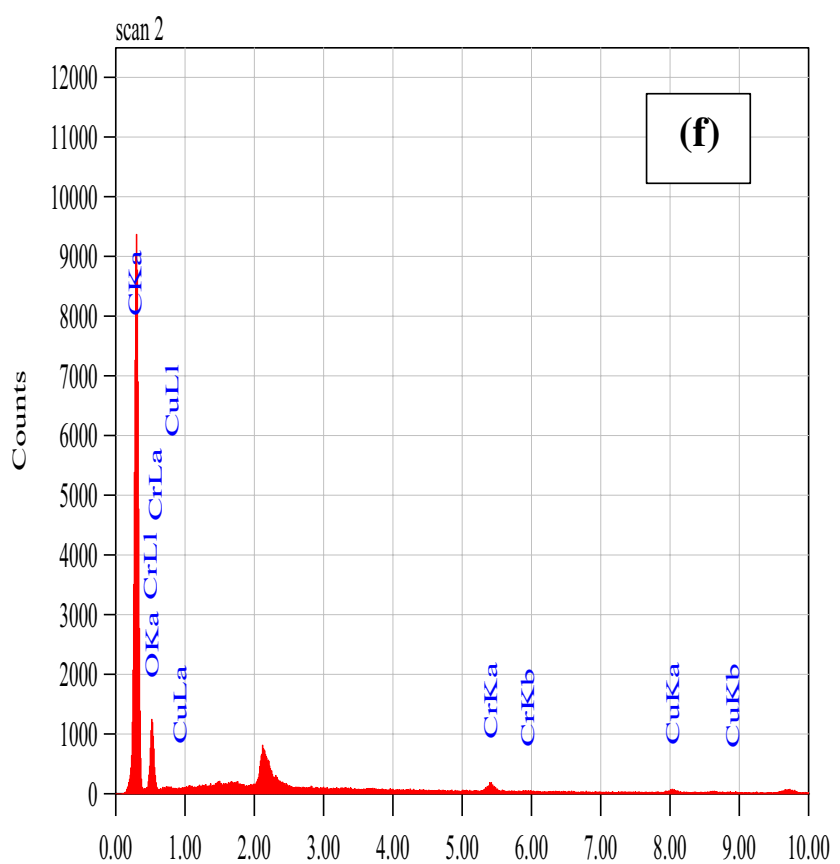

$\mathrm{keV}$

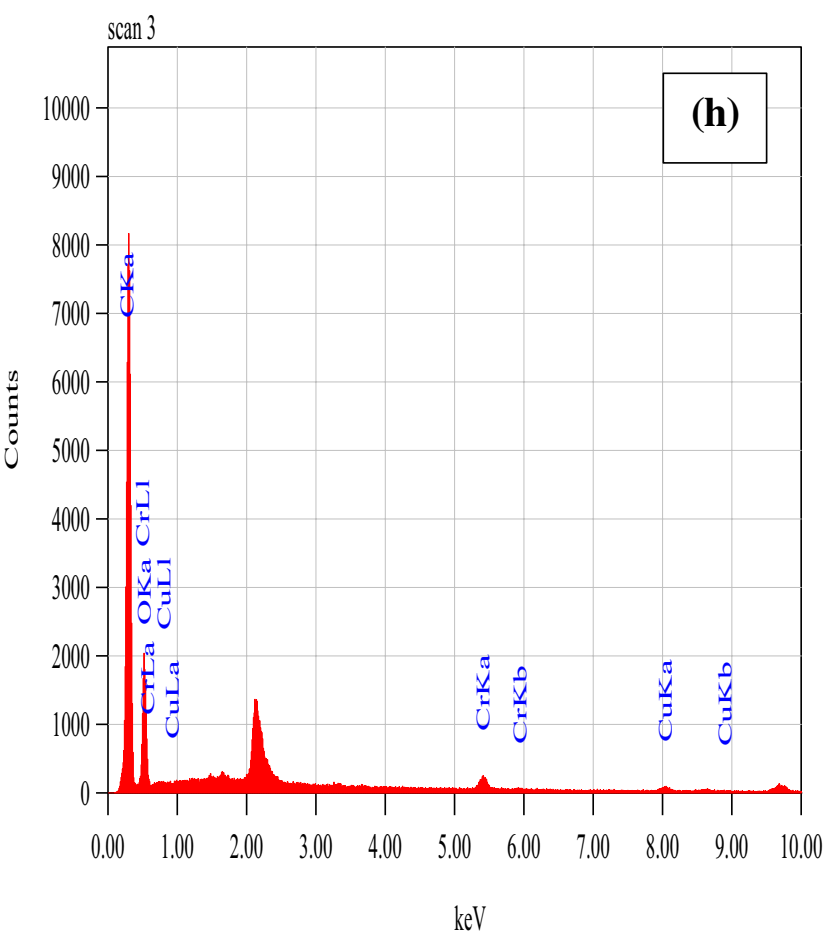

For pseudo second order reaction, the equation is

$t / q_{t}=1 / k_{2} q_{e}^{2}+t / q_{e}$

where $\mathrm{K}_{1}$ for pseudo first order and $\mathrm{K}_{2}$ for pseudo second order rate constants. At time $t$ ( $\mathrm{min}$ ) the quantity of 


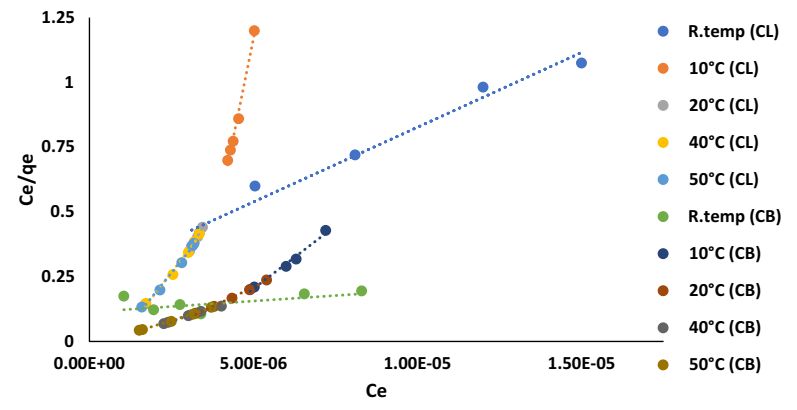

Fig. 4 Langmuir Isotherm for $\mathrm{CL}$ and $\mathrm{CB}$

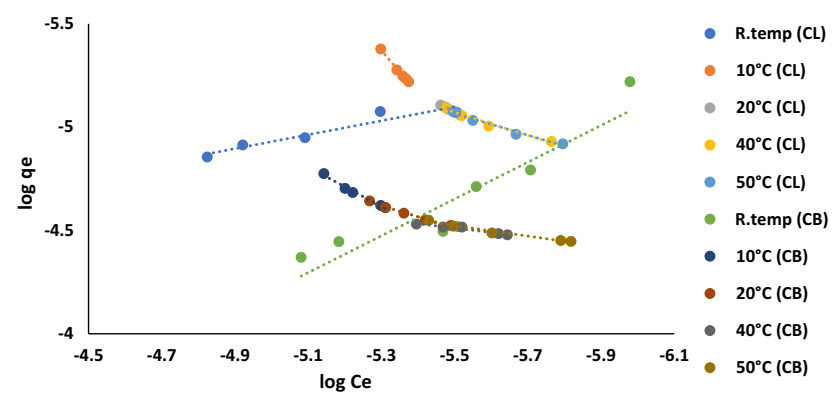

Fig. 5 Freundlich Isotherm for $C L$ and $C B$

sorption is $q_{t}(\mathrm{mg} / \mathrm{g})$ whereas, $q_{e}(\mathrm{mg} / \mathrm{g})$ is the amount of sorption at equilibrium. In pseudo first order the chart was designed between $\log \left(\mathrm{q}_{\mathrm{e}}-\mathrm{q}_{\mathrm{t}}\right)$ and $\mathrm{t}$ while in pseudo second order, it was in between $\mathrm{t} / \mathrm{q}_{\mathrm{e}}$ and $\mathrm{t}$. Adsorption kinetics were investigated with the fixed concentration of $\mathrm{Cr}^{+6}$ metal ions solution and bio-sorbents dose. Sample mixtures were kept for 5 to 100 min with different breaks of time, as mentioned in Table 5. The summarized results of estimating values of equilibrium sorption capacities $\left(\mathrm{q}_{\mathrm{e}}\right)$ for $C L$ and $C B$, do not agree with the experimental values in front of a pseudo first order. However, the determined quantities of equilibrium sorption capacities in pseudo second order plot have shown worthy agreement with the experimental values for the same sorbents respectively.

To excuse the second order kinetics, Elovich equation was employed by assuming actual solid surfaces to be energetically heterogeneous Fig. 9a. Elovich equation is expressed as

$\mathrm{q}_{\mathrm{t}}=\alpha+\beta_{\mathrm{E}} \ln \mathrm{t}$

where $\alpha$ is the preliminary adsorption rate ( $\mathrm{mmol} / \mathrm{g} \cdot \mathrm{min})$ and $\beta_{E}$ is associated with the energy of activation for chemisorption and degree of surface exposure $(\mathrm{g} / \mathrm{mol})$. Elovich equation is simplified by; if $a . \beta_{E} t \gg>1$ and taking into account, the boundary environments $\mathrm{q}_{\mathrm{t}}=0$ at $\mathrm{t}=0$, the calculation improves as,

$\mathrm{q}_{\mathrm{t}}=\frac{1}{\beta \mathrm{E}} \ln \left(\alpha \beta_{\mathrm{E}}\right)+\beta_{\mathrm{E}} \ln \mathrm{t}$

Validity of Elovich equation was tested by plotting values of $q_{t}$ verses Int. If a straight line is obtained, the parameter $\beta_{E}$ is estimated from the gradient of the slope and the intercept of the line made the value of initial sorption rate a. If Elovich equation is valid, it favors the assumption that chemisorption mechanism can describe adsorption rate as represented in Table 5.

According to Weber Morris Equation,

$\mathrm{q}_{\mathrm{t}}=\mathrm{k}_{\mathrm{i}} \sqrt{t}+\mathrm{C}$

The Intra- particle diffusion step controls the degree of adsorption and the up taking of adsorbate differs with the square root of contact time. Therefore, adsorption proportions often calculate for values of adsorption capacities as a function of the square root of interaction time Fig. $9 \mathrm{~b}$. Where $k_{i}$ is the intra-particle diffusion constant and $C$ is a measure of the thickness of the borderline film.
Table 2 Constant parameters of Langmuir and Freundlich adsorption isotherms

\begin{tabular}{|c|c|c|c|c|c|c|}
\hline \multirow[t]{2}{*}{ Adsorbents } & \multirow[t]{2}{*}{ Temperature } & \multicolumn{3}{|c|}{ Langmuir Isotherm } & \multicolumn{2}{|c|}{ Freundlich Isotherm } \\
\hline & & $q_{m}(m g / g)$ & $\mathrm{KL}$ & $\mathrm{RL}$ & $\mathrm{n}$ & $\mathrm{KF}(\mathrm{mg} / \mathrm{g})$ \\
\hline \multirow[t]{5}{*}{$\mathrm{CL}$} & Room & 11.331 & -0.633 & 1.000 & 1.299 & $8.68 \mathrm{E}-01$ \\
\hline & $10^{\circ} \mathrm{C}$ & 1.666 & -3.074 & 1.000 & 0.480 & $4.03 \mathrm{E}-11$ \\
\hline & $20^{\circ} \mathrm{C}$ & 4.500 & -6.222 & 1.000 & 1.096 & $8.48 \mathrm{E}-05$ \\
\hline & $40^{\circ} \mathrm{C}$ & 6.343 & -10.911 & 1.000 & 1.791 & $7.50 \mathrm{E}-03$ \\
\hline & $50^{\circ} \mathrm{C}$ & 6.663 & -11.881 & 1.000 & 1.904 & $1.15 \mathrm{E}-02$ \\
\hline \multirow[t]{5}{*}{$C B$} & Room & 17.320 & -1.231 & 1.000 & 1.124 & $1.74 \mathrm{E}+01$ \\
\hline & $10^{\circ} \mathrm{C}$ & 10.716 & -3.310 & 1.000 & 1.052 & $2.21 \mathrm{E}-09$ \\
\hline & $20^{\circ} \mathrm{C}$ & 17.484 & -6.455 & 1.000 & 1.876 & $3.59 \mathrm{E}-07$ \\
\hline & $40^{\circ} \mathrm{C}$ & 26.855 & -19.302 & 1.000 & 4.787 & $2.19 \mathrm{E}-05$ \\
\hline & $50^{\circ} \mathrm{C}$ & 26.064 & -19.580 & 1.000 & 3.992 & $1.26 \mathrm{E}-05$ \\
\hline
\end{tabular}


Table 3 Values of $\Delta \mathrm{G}^{\circ}, \Delta \mathrm{H}^{\circ}$ and $\Delta \mathrm{S}^{\circ}$ at various temperatures with different adsorbents

\begin{tabular}{|c|c|c|c|c|c|c|c|c|c|c|c|}
\hline \multicolumn{12}{|c|}{ Thermodynamics } \\
\hline \multirow[t]{2}{*}{ Adsorbents } & \multirow[t]{2}{*}{ Temperature } & \multicolumn{2}{|l|}{$10 \mathrm{~min}$} & \multicolumn{2}{|l|}{$20 \min$} & \multicolumn{2}{|l|}{$30 \mathrm{~min}$} & \multicolumn{2}{|l|}{$50 \mathrm{~min}$} & \multicolumn{2}{|l|}{$60 \mathrm{~min}$} \\
\hline & & $\Delta \mathrm{G}^{\circ}$ & & $\Delta \mathrm{G}^{\circ}$ & & $\Delta \mathrm{G}^{\circ}$ & & $\Delta \mathrm{G}^{\circ}$ & & $\Delta \mathbf{G}^{\circ}$ & \\
\hline \multirow[t]{4}{*}{$\mathrm{CL}$} & $10^{\circ} \mathrm{C}$ & -1.22 & $\Delta \mathrm{H}^{\circ}$ & -3.53 & $\Delta \mathrm{H}^{\circ}$ & -6.00 & $\Delta \mathrm{H}^{\circ}$ & -7.04 & $\Delta \mathrm{H}^{\circ}$ & -8.34 & $\Delta \mathrm{H}^{\circ}$ \\
\hline & $20^{\circ} \mathrm{C}$ & -19.73 & 145.05 & -20.95 & 135.77 & -21.84 & 154.41 & -23.74 & 226.49 & -25.37 & -316.37 \\
\hline & $40^{\circ} \mathrm{C}$ & -22.58 & $\Delta S^{\circ}$ & -24.60 & $\Delta \mathrm{S}$ & -27.50 & $\Delta \mathrm{S}$ & -34.82 & $\Delta S^{\circ}$ & -49.37 & $\Delta S^{\circ}$ \\
\hline & $50^{\circ} \mathrm{C}$ & -25.80 & 0.54 & -26.42 & 0.51 & -31.62 & 0.58 & -42.90 & 0.84 & -53.54 & 1.16 \\
\hline \multirow[t]{4}{*}{$\mathrm{CB}$} & $10^{\circ} \mathrm{C}$ & -19.69 & $\Delta \mathrm{H}^{\circ}$ & -26.61 & $\Delta \mathrm{H}^{\circ}$ & -28.78 & $\Delta \mathrm{H}^{\circ}$ & -36.26 & $\Delta \mathrm{H}^{\circ}$ & -37.39 & $\Delta \mathrm{H}^{\circ}$ \\
\hline & $20^{\circ} \mathrm{C}$ & -34.64 & 214.72 & -38.83 & 207.61 & -43.08 & 239.17 & -48.19 & 274.14 & -53.48 & 267.15 \\
\hline & $40^{\circ} \mathrm{C}$ & -49.28 & $\Delta S^{\circ}$ & -55.52 & $\Delta S^{\circ}$ & -59.39 & $\Delta \mathrm{S}^{\circ}$ & -67.16 & $\Delta S^{\circ}$ & -68.94 & $\Delta S^{\circ}$ \\
\hline & $50^{\circ} \mathrm{C}$ & -53.76 & 0.84 & -59.57 & 0.83 & -68.02 & 0.95 & -81.76 & 1.10 & -83.70 & 1.08 \\
\hline
\end{tabular}

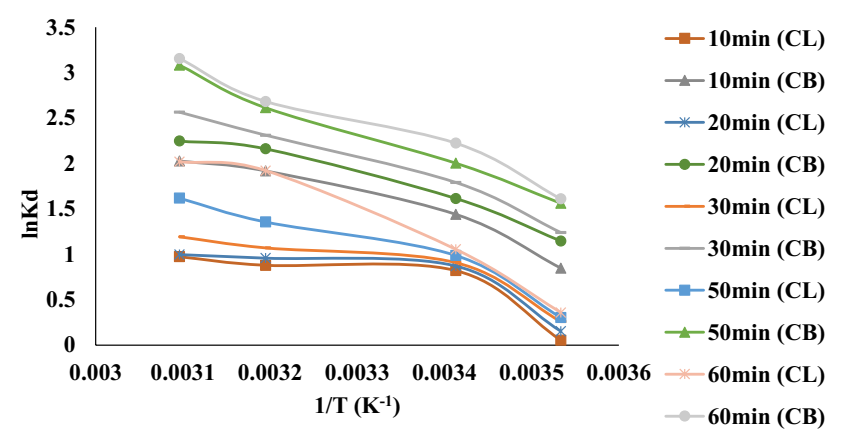

Fig. 6 Thermodynamic plots at different time periods

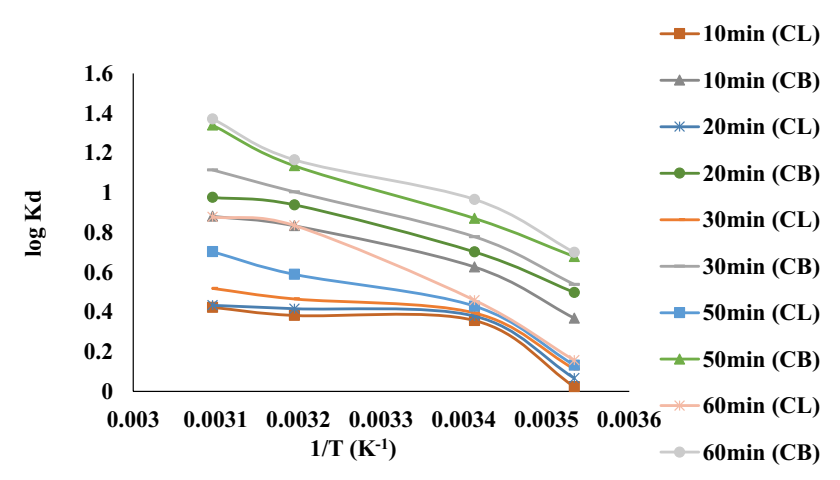

Fig. 7 Graphical representation of Arrhenius Equation at different time periods

\section{Conclusion}

In this study, the optimizations and feasibility of different factors like variations of concentration, mass, stirring time and $\mathrm{pH}$ along with thermodynamic study and kinetic
Table 4 Values of Arrhenius Equation factors

\begin{tabular}{llll}
\hline \multicolumn{2}{l}{ Arrhenius equation } & & \\
\hline Adsorbents & Time & $\mathrm{A}$ & $\mathrm{E}_{\mathrm{A}}$ \\
\hline $\mathrm{CL}$ & $10 \mathrm{~min}$ & $6.84 \mathrm{E}+02$ & $1.45 \mathrm{E}+02$ \\
& $20 \mathrm{~min}$ & $5.01 \mathrm{E}+02$ & $1.36 \mathrm{E}+02$ \\
& $30 \mathrm{~min}$ & $1.19 \mathrm{E}+03$ & $1.54 \mathrm{E}+02$ \\
& $50 \mathrm{~min}$ & $2.68 \mathrm{E}+04$ & $2.27 \mathrm{E}+02$ \\
& $60 \mathrm{~min}$ & $1.32 \mathrm{E}+06$ & $3.16 \mathrm{E}+02$ \\
$\mathrm{CB}$ & $10 \mathrm{~min}$ & $2.73 \mathrm{E}+04$ & $2.15 \mathrm{E}+02$ \\
& $20 \mathrm{~min}$ & $2.59 \mathrm{E}+04$ & $2.08 \mathrm{E}+02$ \\
& $30 \mathrm{~min}$ & $1.11 \mathrm{E}+05$ & $2.39 \mathrm{E}+02$ \\
& $50 \mathrm{~min}$ & $6.37 \mathrm{E}+05$ & $2.74 \mathrm{E}+02$ \\
& $60 \mathrm{~min}$ & $5.37 \mathrm{E}+05$ & $2.67 \mathrm{E}+02$ \\
\hline
\end{tabular}

modeling were investigated for the bio-sorption of hazardous $\mathrm{Cr}^{+6}$ metal ions. Therefore, the rate of adsorption of $\mathrm{Cr}^{+6}$ metal ions decreases as a result of gain in the initial adsorption of solution, while the opposite trend was attained in the case of removal of metal ion from aqueous solution due to the presence of specific adsorption places of both bio-sorbents i.e. $\mathrm{CL}$ and $\mathrm{CB}$. In case of variable dose of both adsorbents vices versa tendency obtained due to the gradual increase in adsorption sites with fixed $\mathrm{Cr}^{+6}$ metal ion concentration. However, lower than $3 \mathrm{pH}$ of solution shows the appreciable amount of adsorption. In the considered $\mathrm{Cr}^{+6}$ metal ion concentration range, biosorption capacities raised with growing initial $\mathrm{Cr}^{+6}$ metal ion concentrations and temperatures. In 
(a)

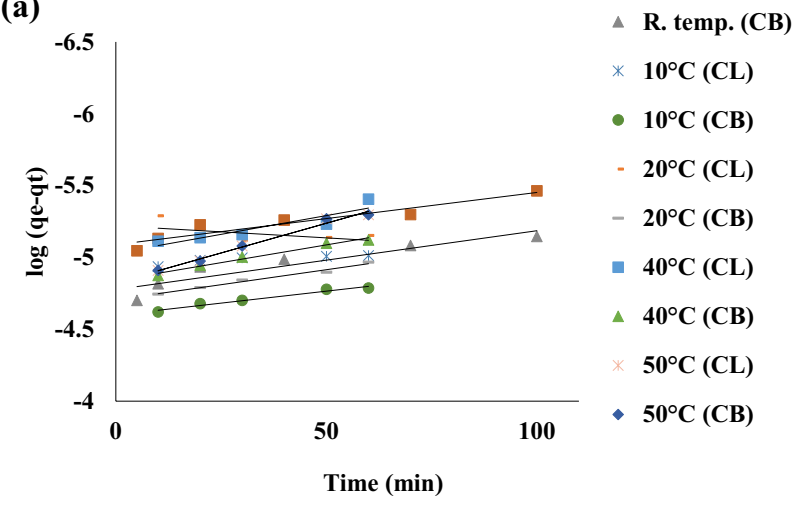

(b)

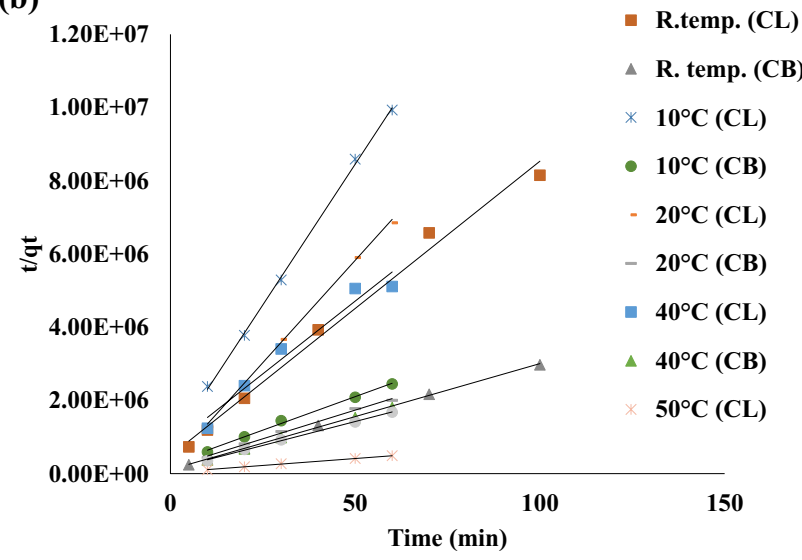

the isotherm models dual parameters were worn to report mathematically the biosorption equilibrium of $\mathrm{Cr}^{+6}$ metal ions to $\mathrm{CL}$ and $\mathrm{CB}$. It was realized that the biosorption equilibrium data contoured mutually well to Langmuir and Freundlich isotherms. The appropriateness of the Kinetic study, pseudo-first-order, pseudo-second order, intra particle diffusion and Elovich plot for the biosorption of $\mathrm{Cr}^{+6}$ metal ions onto $\mathrm{CL}$ and $\mathrm{CB}$ were scrutinized. The pseudo-second-order kinetic model agrees very well with the dynamical performance for the biosorption of $\mathrm{Cr}^{+6}$ metal ions against $\mathrm{CL}$ and $C B$. Results of $\Delta \mathrm{G}^{\circ}, \Delta \mathrm{H}^{\circ}$ and $\Delta S^{\circ}$ displayed the adsorption is possible, which is spontaneous, endothermic and irreversible in manner under the examined conditions. Hence, between both Cinnamomum Verum leaves and bark the percent adsorption discloses that bark has a greater tendency for the elimination of $\mathrm{Cr}^{+6}$ metal ions as compare to its leaves.

Fig. 8 a Pseudo first Order Kinetics b Pseudo Second Order Kinetics

Table 5 Values of constant parameters of Pseudo first order and Pseudo Second order along with Intra particular diffusion and Elovich Plot

\begin{tabular}{|c|c|c|c|c|c|c|c|c|c|c|}
\hline \multicolumn{11}{|c|}{ Kinetic modeling } \\
\hline \multirow[t]{2}{*}{ Adsorbents } & \multirow[t]{2}{*}{ Temperature } & \multicolumn{2}{|c|}{ Pseudo 1st order } & \multicolumn{2}{|c|}{ Pseudo 2nd order } & \multirow[t]{2}{*}{$q_{e}(\exp )$} & \multicolumn{2}{|c|}{ Intra particle diffusion } & \multicolumn{2}{|c|}{ Elovich plot } \\
\hline & & $\mathrm{K}_{1}$ & $\mathrm{q}_{\mathrm{e}}$ & $\mathrm{K}_{2}$ & $q_{e}$ & & C & $\mathrm{K}_{\mathrm{p}}$ & a & $\beta$ \\
\hline \multirow[t]{5}{*}{$\mathrm{CL}$} & Room & $8.35 \mathrm{E}-03$ & $8.13 \mathrm{E}-06$ & $1.32 \mathrm{E}+04$ & $1.24 \mathrm{E}-05$ & $1.57 \mathrm{E}-05$ & $6.26 \mathrm{E}-06$ & $5.92 \mathrm{E}-07$ & $4.52 \mathrm{E}-06$ & $1.59 \mathrm{E}-06$ \\
\hline & $10^{\circ} \mathrm{C}$ & $3.09 \mathrm{E}-03$ & $1.15 \mathrm{E}-05$ & $3.07 \mathrm{E}+04$ & $6.51 \mathrm{E}-06$ & $1.57 \mathrm{E}-05$ & $3.40 \mathrm{E}-06$ & $3.59 \mathrm{E}-07$ & $2.17 \mathrm{E}-06$ & $9.69 \mathrm{E}-07$ \\
\hline & $20^{\circ} \mathrm{C}$ & $-3.80 \mathrm{E}-03$ & $6.02 \mathrm{E}-06$ & $5.24 \mathrm{E}+04$ & $8.95 \mathrm{E}-06$ & $1.57 \mathrm{E}-05$ & $7.16 \mathrm{E}-06$ & $1.94 \mathrm{E}-07$ & $6.62 \mathrm{E}-06$ & $4.88 \mathrm{E}-07$ \\
\hline & $40^{\circ} \mathrm{C}$ & $1.20 \mathrm{E}-02$ & $9.31 \mathrm{E}-06$ & $8.54 \mathrm{E}+03$ & $1.26 \mathrm{E}-05$ & $1.57 \mathrm{E}-05$ & $5.26 \mathrm{E}-06$ & $7.35 \mathrm{E}-07$ & $3.36 \mathrm{E}-06$ & $1.80 \mathrm{E}-06$ \\
\hline & $50{ }^{\circ} \mathrm{C}$ & $1.37 \mathrm{E}-02$ & $9.16 \mathrm{E}-06$ & $7.79 \mathrm{E}+03$ & $1.33 \mathrm{E}-05$ & $1.58 \mathrm{E}-05$ & $5.36 \mathrm{E}-06$ & $8.00 \mathrm{E}-07$ & $3.26 \mathrm{E}-06$ & 1.97E-06 \\
\hline \multirow[t]{5}{*}{ CB } & Room & $9.45 \mathrm{E}-03$ & $1.67 \mathrm{E}-05$ & $7.27 \mathrm{E}+03$ & $3.46 \mathrm{E}-05$ & 4.07E-05 & $2.02 \mathrm{E}-05$ & $1.46 \mathrm{E}-06$ & $1.55 \mathrm{E}-05$ & $4.04 \mathrm{E}-06$ \\
\hline & $10^{\circ} \mathrm{C}$ & $5.49 \mathrm{E}-03$ & $2.27 \mathrm{E}-05$ & $1.20 \mathrm{E}+04$ & $2.56 \mathrm{E}-05$ & 4.07E-05 & $1.52 \mathrm{E}-05$ & $1.22 \mathrm{E}-06$ & $1.24 \mathrm{E}-05$ & $2.95 \mathrm{E}-06$ \\
\hline & $20^{\circ} \mathrm{C}$ & $7.41 \mathrm{E}-03$ & $1.76 \mathrm{E}-05$ & $1.19 \mathrm{E}+04$ & $3.08 \mathrm{E}-05$ & 4.07E-05 & 2.07E-05 & $1.14 \mathrm{E}-06$ & $1.83 \mathrm{E}-05$ & $2.69 \mathrm{E}-06$ \\
\hline & $40^{\circ} \mathrm{C}$ & 8.27E-03 & $1.25 \mathrm{E}-05$ & $1.87 \mathrm{E}+04$ & $3.39 \mathrm{E}-05$ & 4.07E-05 & $2.61 \mathrm{E}-05$ & $9.31 \mathrm{E}-07$ & $2.40 \mathrm{E}-05$ & $2.25 \mathrm{E}-06$ \\
\hline & $50^{\circ} \mathrm{C}$ & $1.39 \mathrm{E}-02$ & $1.18 \mathrm{E}-05$ & $1.38 \mathrm{E}+04$ & $3.67 \mathrm{E}-05$ & 4.07E-05 & $2.62 \mathrm{E}-05$ & $1.26 \mathrm{E}-06$ & $2.34 \mathrm{E}-05$ & $3.03 E-06$ \\
\hline
\end{tabular}


(a)

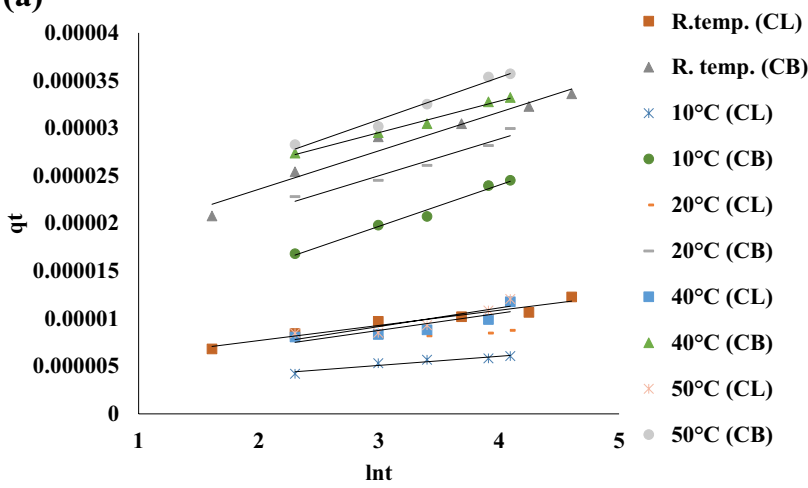

(b)

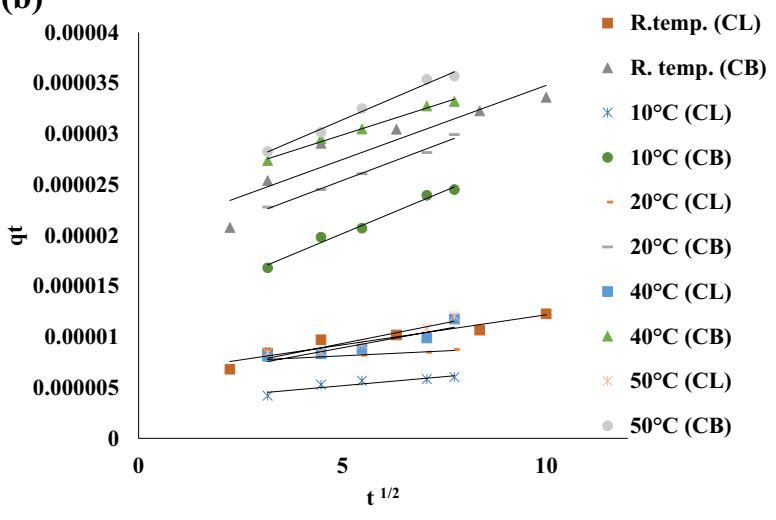

Fig. 9 a Elovich plot $\mathbf{b}$ intra particle diffusion

\section{Compliance with ethical standards}

Conflict of interest The author(s) declare that they have no competing interests.

\section{References}

1. Adebayo G, Mohammed A, Sokoya S (2016) Biosorption of Fe(II) and $\mathrm{Cd}$ (II) ions from aqueous solution using a low cost adsorbent from orange peels. J Appl Sci Environ Manag 20:702-714

2. Ahmad N, Sharma S, Singh V, Shamsi S, Fatma A, Mehta B (2011) Biosynthesis of silver nanoparticles from Desmodium triflorum: a novel approach towards weed utilization. Biotechnol Res Int 2011:1-8

3. Ajmani A, Shahnaz T, Narayanan S, Narayanasamy S (2019) Equilibrium, kinetics and thermodynamics of hexavalent chromium biosorption on pristine and zinc chloride activated Senna siamea seed pods. Chem Ecol 35:379-396

4. Ajmani A, Shahnaz T, Subbiah S, Narayanasamy S (2019) Hexavalent chromium adsorption on virgin, biochar, and chemically modified carbons prepared from Phanera vahlii fruit biomass: equilibrium, kinetics, and thermodynamics approach. Environ Sci Pollut Res 26:32137-32150

5. Ali K, Amin N, Shah MT (2009) Physicochemical study of bagasse and bagasse ash from the sugar industries of NWFP Pakistan and its recycling in cement manufacturing. J Chem Soc Pak $31: 375-378$
6. Amaladhas TP, Sivagami S, Devi TA, Ananthi N, Velammal SP (2012) Biogenic synthesis of silver nanoparticles by leaf extract of Cassia angustifolia. Adv Nat Sci Nanosci Nanotechnol 3:045006

7. Ansari R, Mosayebzadeh Z, Keivani MB, Khah A (2011) Adsorption of cationic dyes from aqueous solutions using polyaniline conducting polymer as a novel adsorbent. J Adv Sci Res 2:27-34

8. Babel S, Kurniawan TA (2004) $\mathrm{Cr}$ (VI) removal from synthetic wastewater using coconut shell charcoal and commercial activated carbon modified with oxidizing agents and/or chitosan. Chemosphere 54:951-967

9. Bhattacharyya KG, Sharma A (2004) Adsorption of Pb(II) from aqueous solution by Azadirachta indica (Neem) leaf powder. J Hazard Mater 113:97-109

10. Bidstrup P, Wagg R (1983) Chromium alloys and compounds. In: Encyclopaedia of occupational health safety, 3rd edn, vol 1. International Labour Office, Geneva, pp 468-472

11. Chen J, Yang ML, Zeng J, Gao K (2013) Antimicrobial activity of Araucaria cunninghamii sweet and the chemical constituents of its twigs and leaves. Phytochem Lett 6:41-45

12. Chopra A, Doiphode VV (2002) Ayurvedic medicine: core concept, therapeutic principles, and current relevance. Med Clin 86:75-89

13. Chuah TG, Jumasiah A, Azni I, Katayon S, Choong ST (2005) Rice husk as a potentially low-cost biosorbent for heavy metal and dye removal: an overview. Desalination 175:305-316

14. Darakas E, Tsiridis V, Petala M, Kungolos A (2013) Hexavalent chromium release from lignite fly ash and related ecotoxic effects. J Environ Sci Health, Part A 48:1390-1398

15. Devaraj M, Saravanan R, Deivasigamani R, Gupta VK, Gracia F, Jayadevan S (2016) Fabrication of novel shape Cu and Cu/ $\mathrm{Cu}_{2} \mathrm{O}$ nanoparticles modified electrode for the determination of dopamine and paracetamol. J Mol Liq 221:930-941

16. Di Bona KR et al (2011) Chromium is not an essential trace element for mammals: effects of a "low-chromium" diet. JBIC, J Biol Inorg Chem 16:381-390

17. Feng Z, Zhu S, Martins de Godoi DR, Samia ACS, Scherson D (2012) Adsorption of $\mathrm{Cd}^{2+}$ on carboxyl-terminated superparamagnetic iron oxide nanoparticles. Anal Chem 84:3764-3770

18. Fiol N, de la Torre F, Demeyere P, Florido A, Villaescusa I (2007) Vegetable waste-based sensors for metal ion determination. Sens Actuators B Chem 122:187-194

19. Flora SJ (2011) Arsenic-induced oxidative stress and its reversibility. Free Radic Biol Med 51:257-281

20. Gardea-Torresdey J et al (2000) Characterization of $\mathrm{Cr}(\mathrm{VI})$ binding and reduction to $\mathrm{Cr}(\mathrm{III})$ by the agricultural byproducts of Avena monida (Oat) biomass. J Hazard Mater 80(1-3):175-188

21. Gode F, Pehlivan E (2005) Removal of $\mathrm{Cr}(\mathrm{VI})$ from aqueous solution by two Lewatit-anion exchange resins. J Hazard Mater 119:175-182

22. Gupta V, Nayak A (2012) Cadmium removal and recovery from aqueous solutions by novel adsorbents prepared from orange peel and $\mathrm{Fe}_{2} \mathrm{O}_{3}$ nanoparticles. Chem Eng J 180:81-90

23. Gupta VK, Jain R, Nayak A, Agarwal S, Shrivastava M (2011) Removal of the hazardous dye-tartrazine by photodegradation on titanium dioxide surface. Mater Sci Eng, C 31:1062-1067

24. Hughes K, Meek M, Seed L, Shedden J (1994) Chromium and its compounds: evaluation of risks to health from environmental exposure in Canada. J Environ Sci Health Part C 12:237-255

25. Janani $\mathrm{K}$ et al (2019) Optimization of EDTA enriched phytoaccumulation of zinc by Ophiopogon japonicus: comparison of response surface Artificial Neural Network and Random Forest models. Bioresour Technol Rep 7:100265

26. Karthik V, Saravanan K, Patra C, Ushadevi B, Vairam S, Selvaraju N (2019) Biosorption of acid yellow 12 from simulated wastewater 
by non-viable T. harzianum: kinetics, isotherm and thermodynamic studies. Int J Environ Sci Technol 16:6895-6906

27. Khani H, Rofouei MK, Arab P, Gupta VK, Vafaei Z (2010) Multiwalled carbon nanotubes-ionic liquid-carbon paste electrode as a super selectivity sensor: application to potentiometric monitoring of mercury ion (II). J Hazard Mater 183:402-409

28. Khatoon S, Anwar J, Mukhtar-ul-Hassan HBF, Khalid HN, Ahmad D (2009) Removal of chromium (vi) by using eucalyptus bark (biosorption). J Sci Res 39:41-48

29. Kumar S, Narayanasamy S, Venkatesh RP (2019) Removal of $\mathrm{Cr}(\mathrm{VI})$ from synthetic solutions using water caltrop shell as a low-cost biosorbent. Sep Sci Technol 54:2783-2799

30. Larous S, Meniai A-H, Lehocine MB (2005) Experimental study of the removal of copper from aqueous solutions by adsorption using sawdust. Desalination 185:483-490

31. Li J et al (2018) Metal-organic framework-based materials: superior adsorbents for the capture of toxic and radioactive metal ions. Chem Soc Rev 47:2322-2356

32. Li X, Liu S, Na Z, Lu D, Liu Z (2013) Adsorption, concentration, and recovery of aqueous heavy metal ions with the root powder of Eichhornia crassipes. Ecol Eng 60:160-166

33. Luna C, Chávez V, Barriga-Castro ED, Núñez NO, Mendoza-Reséndez R (2015) Biosynthesis of silver fine particles and particles decorated with nanoparticles using the extract of Illicium verum (star anise) seeds. Spectrochim Acta Part A Mol Biomol Spectrosc 141:43-50

34. McCarron P, Harvey I, Brogan R, Peters TJ (2000) Self reported health of people in an area contaminated by chromium waste: interview study. BMJ 320:11-15

35. Meo MI, Haydar S, Nadeem O, Hussain G, Rashid H (2014) Characterization of hospital wastewater, risk waste generation and management practices in lahore. Proc Pak Acad Sci 51:317-319

36. Mertz W (1993) Chromium in human nutrition: a review. J Nutr 123:626-633

37. Mittal A, Mittal J, Malviya A, Kaur D, Gupta V (2010) Decoloration treatment of a hazardous triarylmethane dye, Light Green SF (Yellowish) by waste material adsorbents. J Colloid Interface Sci 342:518-527

38. Nakkeeran E, Patra C, Shahnaz T, Rangabhashiyam S, Selvaraju $\mathrm{N}$ (2018) Continuous biosorption assessment for the removal of hexavalent chromium from aqueous solutions using Strychnos nux vomica fruit shell. Bioresour Technol Rep 3:256-260

39. Osasona I, Ojo Adebayo A, Ajayi OO (2013) Adsorptive removal of chromium (VI) from aqueous solution using cow hooves. Adsorpt Remov Chromium Aqueous Solut Using Cow Hooves 2:1-16

40. Pons MP, Fuste MC (1993) Uranium uptake by immobilized cells of Pseudomonas strain EPS 5028. Appl Microbiol Biotechnol 39:661-665

41. Rafati L, Mahvi A, Asgari A, Hosseini S (2010) Removal of chromium (VI) from aqueous solutions using Lewatit FO36 nano ion exchange resin. Int J Environ Sci Technol 7:147-156

42. Rangabhashiyam S, Suganya E, Lity AV, Selvaraju N (2016) Equilibrium and kinetics studies of hexavalent chromium biosorption on a novel green macroalgae Enteromorpha sp. Res Chem Intermed 42:1275-1294
43. Saleh TA, Gupta VK (2012) Photo-catalyzed degradation of hazardous dye methyl orange by use of a composite catalyst consisting of multi-walled carbon nanotubes and titanium dioxide. J Colloid Interface Sci 371:101-106

44. Samuel MS, Subramaniyan V, Bhattacharya J, Parthiban C, Chand S, Singh NP (2018) A GO-CS@ MOF [Zn (BDC)(DMF)] material for the adsorption of chromium (VI) ions from aqueous solution. Compos Part B Eng 152:116-125

45. Saravanan R, Gupta V, Narayanan V, Stephen A (2014) Visible light degradation of textile effluent using novel catalyst $\mathrm{ZnO} / \mathrm{Y}^{-}$ Mn2O3. J Taiwan Inst Chem Eng 45:1910-1917

46. Saravanan R, Gupta V, Prakash T, Narayanan V, Stephen A (2013) Synthesis, characterization and photocatalytic activity of novel $\mathrm{Hg}$ doped $\mathrm{ZnO}$ nanorods prepared by thermal decomposition method. J Mol Liq 178:88-93

47. Saravanan R, Prakash T, Gupta V, Stephen A (2014) Tailoring the electrical and dielectric properties of $\mathrm{ZnO}$ nanorods by substitution. J Mol Liq 193:160-165

48. Solomon J, Devaprasath P, Chandramohan M (2012) Removal of $\mathrm{Cu}$ (II) from aqueous solution by using natural plant material Cynodon dactylon. Res J Pharm Biol Chem Sci 3:304-321

49. Srivastava V, Shekhar M, Gusain D, Gode F, Sharma YC (2017) Application of a heterogeneous adsorbent (HA) for the removal of hexavalent chromium from aqueous solutions: kinetic and equilibrium modeling. Arab J Chem 10:S3073-S3083

50. Srivastava VC, Swamy MM, Mall ID, Prasad B, Mishra IM (2006) Adsorptive removal of phenol by bagasse fly ash and activated carbon: equilibrium, kinetics and thermodynamics. Colloids Surf Physicochem Eng Asp 272:89-104

51. Suganya E, Saranya N, Patra C, Varghese LA, Selvaraju N (2019) Biosorption potential of Gliricidia sepium leaf powder to sequester hexavalent chromium from synthetic aqueous solution. J Environ Chem Eng 7:103112

52. Waalkes MP (2000) Cadmium carcinogenesis in review. J Inorg Biochem 79:241-244

53. Weckhuysen BM, Wachs IE, Schoonheydt RA (1996) Surface chemistry and spectroscopy of chromium in inorganic oxides. Chem Rev 96:3327-3350

54. Xu M, Hadi P, Chen G, McKay G (2014) Removal of cadmium ions from wastewater using innovative electronic waste-derived material. J Hazard Mater 273:118-123

55. Xu Y, Zhao D (2007) Reductive immobilization of chromate in water and soil using stabilized iron nanoparticles. Water Res 41:2101-2108

56. Yang J, Li C, Yang B, Kang S, Zhang Z (2018) Study on adsorption of chromium ( $\mathrm{VI}$ ) by activated carbon from cassava sludge. In: IOP conference series: earth and environmental science, vol 1. IOP Publishing, p 012017

57. Zhu L, Liu Y, Chen J (2009) Synthesis of N-methylimidazolium functionalized strongly basic anion exchange resins for adsorption of $\mathrm{Cr}(\mathrm{VI})$. Ind Eng Chem Res 48:3261-3267

Publisher's Note Springer Nature remains neutral with regard to jurisdictional claims in published maps and institutional affiliations. 